\title{
Analisis Risiko Bencana Kebakaran Di Kecamatan Tambora Kota Administrasi Jakarta Barat
}

\author{
Fire Risk Analysis of Tambora Sub District, West Jakarta
}

\author{
Nuniek Sutanti ${ }^{1}$, Boedi Tjahjono² dan Lailan Syaufina ${ }^{3}$
}

Diterima: 26 November 2018

Disetujui: 6 September 2019

\begin{abstract}
Abstrak: Kecamatan Tambora merupakan kecamatan yang mempunyai luas wilayah terkecil di Jakarta Barat dengan jumlah penduduk terbesar sehingga Kecamatan Tambora menjadi kawasan yang padat. Kepadatan penduduk yang tidak diimbangi dengan daya dukung lingkungan menyebabkan suatu daerah menjadi kumuh dan rawan terjadi bencana kebakaran. Penelitian ini bertujuan untuk menganalisis tingkat risiko bencana kebakaran di Kecamatan Tambora, Jakarta Barat. Metodologi yang digunakan dalam penelitian ini adalah analisis Multi Criteria Evaluation (MCE) dan analisis risiko bencana kebakaran dengan mempertimbangkan keterkaitan antara variabel bahaya dan kerentanan. Hasil analisis risiko bencana kebakaran menunjukkan bahwa tingkat risiko kebakaran yang paling dominan adalah tingkat risiko sedang sebesar $65,7 \%$, tingkat risiko tinggi sebesar $27,8 \%$ dan yang terkecil adalah tingkat risiko rendah 6,5\%. Dilihat dari besarnya luas wilayah yang masuk ke dalam risiko kebakaran sedang dan tinggi, Kecamatan Tambora merupakan kecamatan yang rawan terjadi kebakaran dan memiliki potensi kerugian yang besar baik kerugian harta benda maupun jatuhnya korban jiwa.
\end{abstract}

Kata kunci: bahaya, kerentanan, permukiman kumuh, analisis Multi Criteria Evaluation

\begin{abstract}
Tambora sub-district is a sub-district that has the smallest area in West Jakarta with the largest population, causing Tambora sub-district to be a densely populated area. Population density which is not matched by the carrying capacity of the environment causes a region to become slum and prone to fire disasters. This study aims to analyze the level of risk of fire disasters in Tambora Subdistrict, West Jakarta. The methodology used in this study were the Multi Criteria Evaluation (MCE) analysis and fire disaster risk analysis by considering the relationship between the hazard and vulnerability variables. The results of the fire disaster risk analysis showed that the most dominant level of fire risk was a moderate risk level of $65.7 \%$, a high risk level of $27.8 \%$ and the smallest was a low risk level of $6.5 \%$. Viewed from the size of the area included in the medium and high risk of fire, indicating that Tambora Subdistrict is a subdistrict prone to fire and has a large potential loss of both property and life.
\end{abstract}

Keywords: hazard, vulnerability, slum area, multi criteria evaluation analysis

\footnotetext{
${ }^{1}$ Magister Perencanaan Wilayah, Sekolah Pascasarjana Institut Pertanian Bogor

${ }^{2}$ Departemen Ilmu Tanah dan Sumberdaya Lahan, Fakultas Pertanian, Institut Pertanian Bogor

${ }^{3}$ Departemen Silvikultur, Fakultas Kehutanan, Institut Pertanian Bogor
} 


\section{PENDAHULUAN}

Bertambahnya jumlah penduduk Jakarta yang diakibatkan oleh arus urbanisasi menyebabkan terjadinya pemadatan penduduk (urban densification) yang kemudian akan diikuti dengan semakin meluasnya pengembangan wilayah terbangun untuk memenuhi kebutuhan akan perumahan (Suweda, 2011). Tingginya permintaan lahan untuk tempat bermukim menimbulkan kompetisi yang tinggi sehingga terbentuklah pola-pola permukiman. Salah satu pola permukiman yang terbentuk adalah pola permukiman yang mempunyai tingkat kepadatan tinggi baik dari segi jumlah penduduknya maupun dari kerapatan bangunannya. Pada kawasan permukiman yang padat disertai dengan penurunan daya dukung lingkungan serta sarana prasarana lingkungan yang tidak memadai menyebabkan terbentuknya permukiman kumuh (slum area). Mononimbar et al. (2018) menyatakan bahwa kawasan kumuh merupakan wilayah yang memiliki kondisi lingkungan yang buruk, kotor, berpenduduk padat, serta keterbatasan ruang untuk ventilasi, cahaya, udara, sanitasi, lapangan terbuka, dan kondisi yang ada seringkali menimbulkan dampak yang membahayakan kehidupan manusia (misalnya kebakaran dan kriminalitas) sebagai akibat kombinasi berbagai faktor. Kebakaran merupakan bencana antropogenik yang sering terjadi pada kawasan permukiman. Menurut Ramli (2010) dalam Fransisca et al. (2014) kebakaran adalah api yang tidak terkendali di luar kemampuan dan keinginan manusia sehingga merupakan musibah yang sering terjadi di tengah masyarakat khususnya di daerah permukiman, tempat kerja, dan perkotaan serta menimbulkan kerugian yang besar baik korban jiwa, cidera maupun kerugian materil. Api terjadi karena ada proses pembakaran antara tiga unsur yang bersatu dimana jika salah satu unsur tidak ada maka proses pembakaran tidak akan terjadi. Unsur-unsur tersebut dikenal dengan istilah segitiga api (fire triangle) yaitu bahan bakar, oksigen, dan panas (Syaufina, 2008).

Kecamatan Tambora merupakan kecamatan yang memiliki luas wilayah terkecil di Kota Jakarta Barat yaitu seluas $5,4 \mathrm{~km}^{2}$ tetapi memiliki jumlah penduduk yang tinggi yaitu sebesar 267.375 jiwa. Tingkat kepadatan penduduk di Kecamatan Tambora menempati urutan tertinggi kedua di DKI Jakarta yaitu sebesar 49.240 jiwa $/ \mathrm{km}^{2}$ (BPS, 2017a). Tingginya kepadatan penduduk di Kecamatan Tambora menimbulkan fenomena perkotaan yang semakin rumit seperti menurunnya kualitas lingkungan dan terjadinya bencana kebakaran di permukiman. Berdasarkan data yang diperoleh dari Dinas Penanggulangan Kebakaran dan Penyelamatan Provinsi DKI Jakarta jumlah kejadian kebakaran di Kecamatan Tambora pada tahun 2017 meningkat sebesar 65\% dari tahun 2016 (Gambar 1).

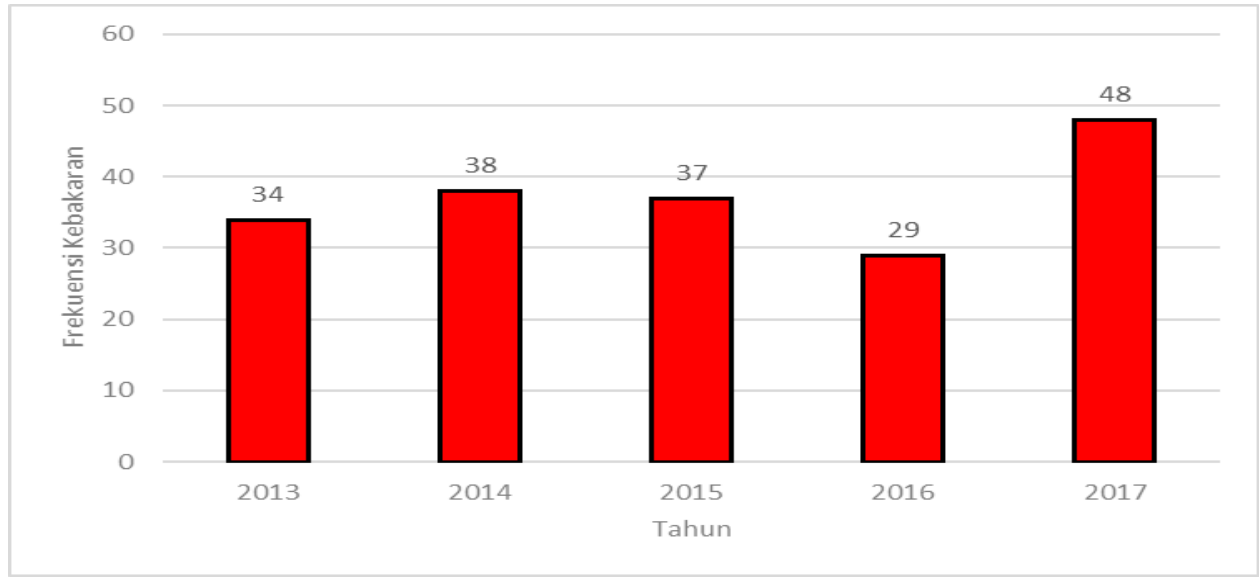

Sumber: Dinas Penanggulangan Kebakaran dan Penyelamatan Prov. DKI Jakarta

Gambar 1 Jumlah Kejadian Kebakaran Tahun 2013-2017 di Kecamatan Tambora 
Data Dinas Penanggulangan Kebakaran dan Penyelamatan Provinsi DKI Jakarta juga mencatat kejadian kebakaran di Kecamatan Tambora menyebabkan perumahan menduduki peringkat tertinggi sebagai sarana atau obyek yang terbakar sejak tahun 2013 sampai dengan tahun 2017 (Gambar 2).

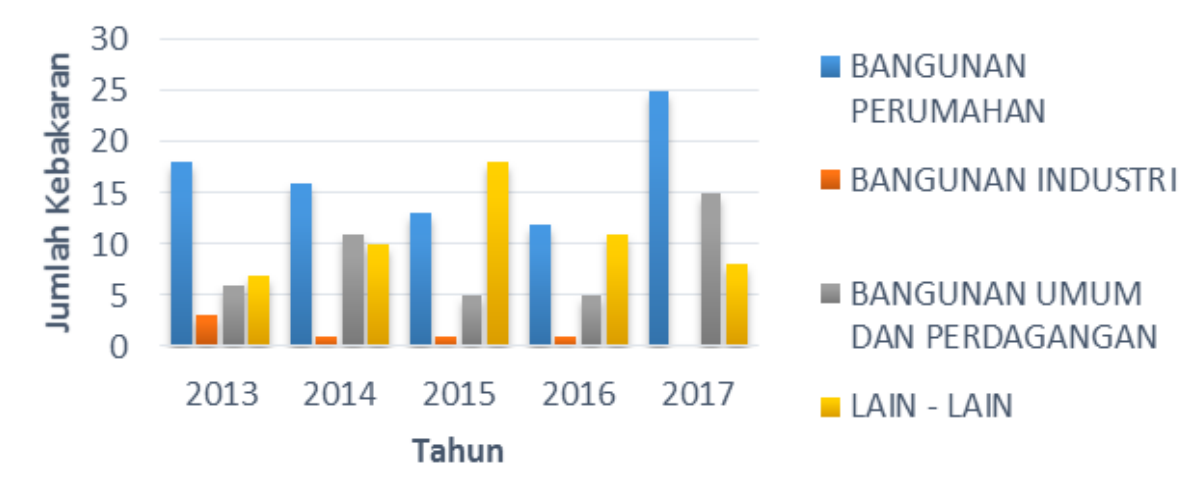

Sumber: Dinas Penanggulangan Kebakaran dan Penyelamatan Prov. DKI Jakarta

\section{Gambar 2 Jumlah Kejadian Kebakaran menurut Sarana yang Terbakar Tahun 2013-2017 di Kecamatan Tambora}

Kebakaran yang terjadi di daerah permukiman disebabkan oleh berbagai faktor, seperti hubungan pendek arus listrik, pembakaran sampah maupun kondisi lingkungan permukiman yang buruk seperti yang dijumpai di permukiman kumuh (Oktaviansyah, 2012). Faktor lain yang menyebabkan terjadinya kebakaran di permukiman menurut Adilla et al. (2016) adalah jarak bangunan yang sangat rapat atau menempel satu dengan yang lain. Kebakaran di Kecamatan Tambora berdasarkan data dari Dinas Penanggulangan Kebakaran dan Penyelamatan Provinsi DKI Jakarta disebabkan sebagian besar oleh hubungan pendek arus listrik (76\%) dan diperparah dengan bentuk permukiman yang padat. Kebakaran di daerah permukiman umumnya menimbulkan kerugian yang besar bagi penghuninya bahkan tidak jarang menimbulkan korban jiwa (Mantra, 2005). Di wilayah DKI Jakarta kebakaran di permukiman padat merupakan masalah kronik yang sulit dicegah dan jumlah kejadiannya cenderung meningkat (Nasution, 2012). Mengingat besarnya potensi kerugian yang ditimbulkan oleh bencana kebakaran maka perlu dilakukan pengkajian tentang risiko kebakaran untuk mengetahui daerah-daerah yang memiliki risiko tinggi, sedang dan rendah. Oleh karena itu penelitian ini bertujuan untuk mengidentifikasi dan memetakan sebaran tingkat risiko bencana kebakaran di Kecamatan Tambora.

\section{METODE PENELITIAN}

\section{Lokasi dan Waktu Penelitian}

Penelitian dilaksanakan di Kecamatan Tambora yang termasuk ke dalam wilayah Kota Administrasi Jakarta Barat, peta wilayah penelitian dapat dilihat pada Gambar 3. Batas wilayah Kecamatan Tambora adalah di sebelah utara berbatasan dengan Kali Angke, sebelah selatan berbatasan dengan rel kereta api Kecamatan Gambir, sebelah barat berbatasan dengan Kali Banjir Kanal dan sebelah timur berbatasan dengan Kali Krukut. Luas wilayah Kecamatan Tambora adalah 542,7 hektar yang terbagi menjadi 11 kelurahan dan 96 RW. Satuan pemetaan yang digunakan dalam penelitian ini adalah wilayah 
permukiman kumuh dan tidak kumuh. Pemprov DKI Jakarta telah mengeluarkan data tentang permukiman kumuh dalam lingkup RW. Berdasarkan data RW Kumuh 2017 Provinsi DKI Jakarta, RW kumuh yang terdapat di Kecamatan Tambora ada sebanyak 15 RW dan tersebar di 8 (delapan) kelurahan (BPS 2017b).

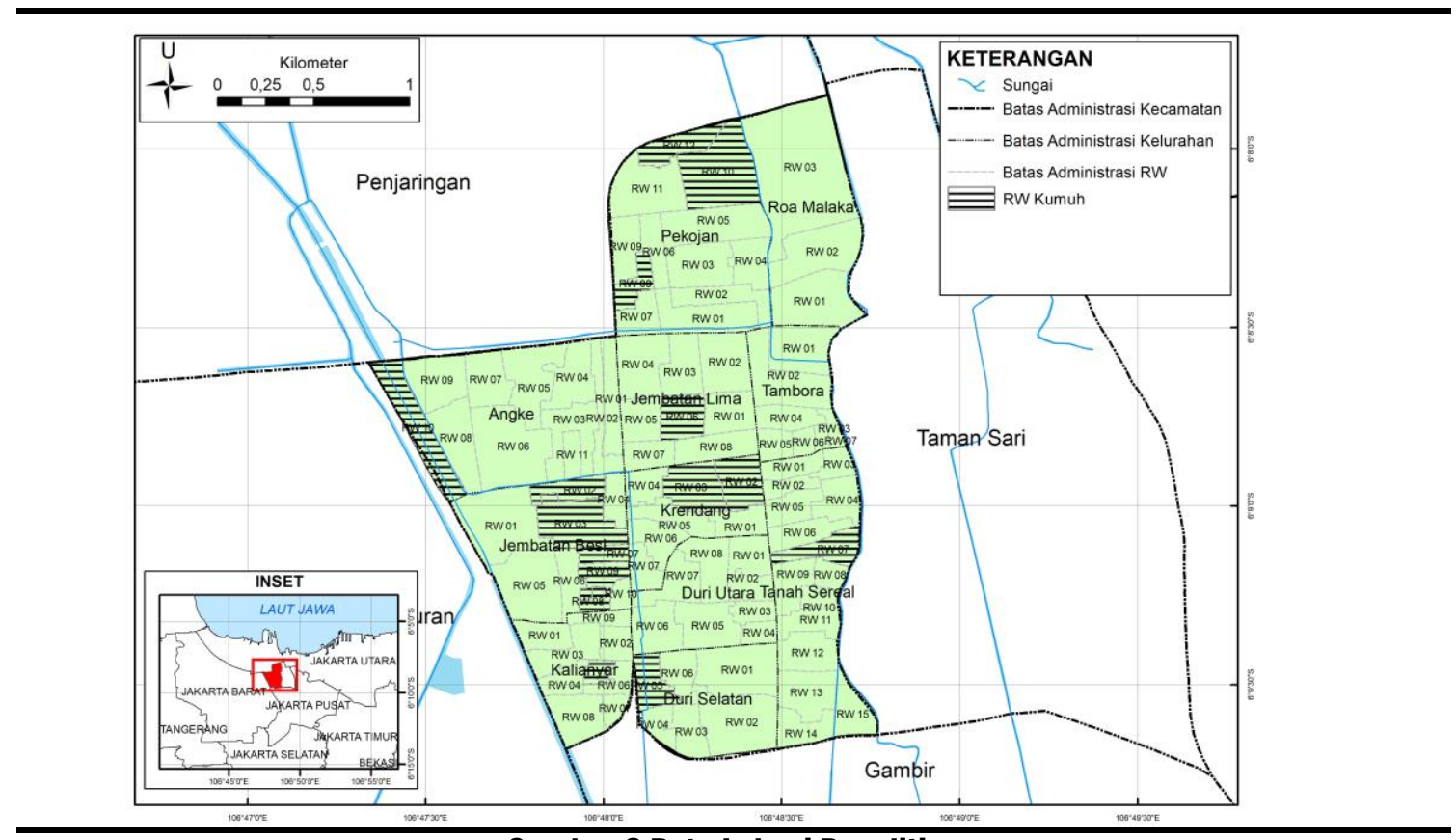

Gambar 3 Peta Lokasi Penelitian

\section{Populasi dan sampel}

Populasi penelitian adalah keseluruhan penduduk di Kecamatan Tambora sebesar 267.375 jiwa, terbagi ke dalam 96 RW (15 RW kumuh dan 81 RW tidak kumuh). Penentuan sampel bertujuan untuk mengetahui tingkat kerentanan penduduk dalam menghadapi bencana kebakaran. Agar kuisioner tersebar merata di wilayah penelitian, maka digunakan teknik proportionate stratified random sampling. Adapun dalam menentukan jumlah sampel dilakukan dengan menggunakan rumus Isaac dan Michael (Hapsari, 2017) dimana dengan menggunakan rumus tersebut (R1) diperoleh jumlah sampel sebanyak 386.

$$
\begin{aligned}
& \mathrm{n}=\frac{\lambda^{2} \text { X N X P X Q }}{\mathrm{d}^{2} \mathrm{X}(\mathrm{N}-1)+\lambda^{2} \text { X P X Q }} \\
& \mathrm{n}=\frac{3,84 \times 267.375 \times 0,5 \times 0,5}{0,05^{2} \mathrm{X}(267.375-1)+3,84 \times 0,5 \times 0,5}=386 \text { responden }
\end{aligned}
$$

\section{Teknik Analisis Data}

Metode analisis yang digunakan dalam penelitian ini meliputi analisis multicriteria evaluation (MCE) untuk menilai tingkat bahaya dan kerentanan dan analisis matriks untuk menilai risiko bencana kebakaran.

\section{Analisis multicriteria evaluation (MCE)}

MCE digunakan untuk menganalisis serangkaian alternatif dengan melihat kepada peringkatnya dengan menggunakan pendekatan terstruktur dan hasil akhirnya berupa bobot yang menunjukkan preferensi dari alternatif (Musungu et al. 2012). Setelah fakor dan sub fakor pembentuk bahaya dan kerentanan dikelompokkan secara terstruktur, kemudian dilakukan pembobotan nilai untuk masing-masing faktor dan sub faktor tersebut. 
Nilai bobot untuk masing-masing faktor dilakukan dengan metode Analytical Hierarchy Process (AHP) dan diolah dengan menggunakan program Expert Choice. Analytical Hierarchy Process (AHP) merupakan metode yang digunakan untuk melakukan pemecahan terhadap suatu permasalahan dengan menentukan urutan prioritas dari berbagai alternatif karena pengambilan suatu keputusan dipengaruhi oleh berbagai macam faktor dan mencakup berbagai jenjang kepentingan (Pawesti et al. 2012). Nilai sub faktor selanjutnya diurutkan terlebih dahulu dengan memberikan urutan yang tertinggi untuk sub faktor yang potensinya paling besar dalam menyumbangkan bahaya kebakaran serta kerentanan. Adapun pemberian skoring untuk masing-masing sub faktor dilakukan dengan ketentuan standarisasi skor skala berkebalikan. Penentuan faktor dan sub faktor secara terstruktur serta pemberian nilai bobot dan skor untuk tingkat bahaya dan kerentanan dapat dilihat pada Tabel 1 dan Tabel 2.

Tabel 1 Nilai Bobot dan Skor Bahaya



\section{Analisis Risiko Bencana Kebakaran}

Pada tahapan analisis bahaya dan kerentanan, ini dilakukan melalui proses overlay menggunakan ArcGIS dengan metode weighted overlay. Pada tahapan analisis risiko bencana kebakaran hasil akhirnya adalah peta risiko yang dibuat berdasarkan operasi tumpang susun (overlay) antara peta bahaya dan peta kerentanan. Kemudian dilakukan penilaian tingkat risiko berdasarkan perkalian matriks sesuai dengan rumus VCA (Vulnerability Capacity Analysis) dari Perka BNPB Nomor 2 Tahun 2012 (BNPB 2012), namun dimodifikasi sehingga tanpa menggunakan aspek kapasitas (Gambar 4). 


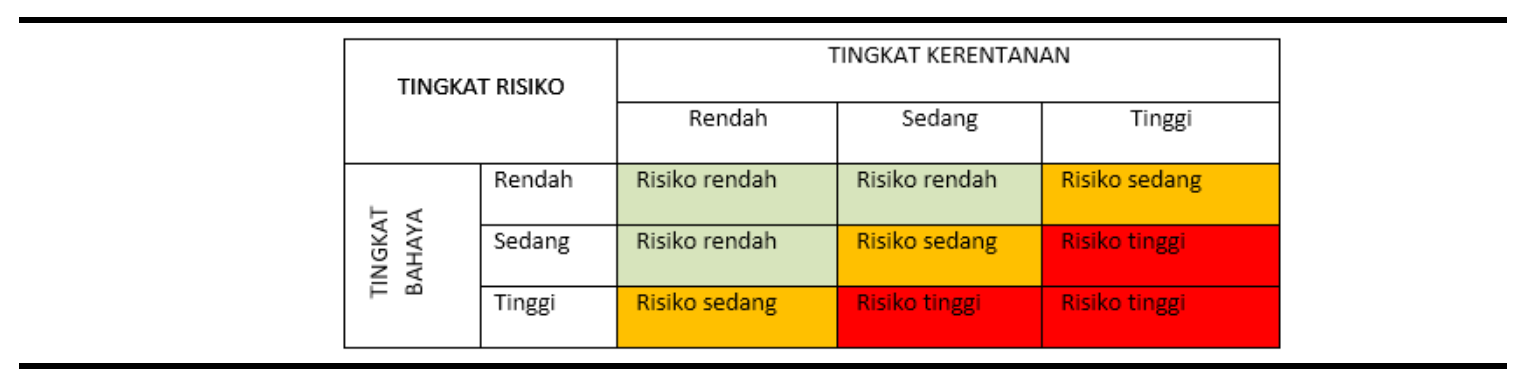

Gambar 4 Matriks Penentuan Tingkat Risiko

\section{HASIL DAN PEMBAHASAN}

\section{Tingkat Bahaya Kebakaran}

Bahaya (hazard) merupakan suatu kejadian yang mempunyai potensi untuk menyebabkan terjadinya kecelakaan, cedera, hilangnya nyawa atau hilangnya harta benda. Menurut Taridala et al. (2018) potensi bahaya tertinggi diperkotaan adalah permukiman dengan karakteristik kepadatan penduduk tinggi, kompleksitas penggunaan lahan, material bangunan yang mudah terbakar, daerah kumuh perkotaan, jaringan jalan yang sempit, tidak tersedianya sumber air untuk pemadaman, dan jumlah stasiun pemadam kebakaran yang minim.

Penilaian bahaya kebakaran dalam penelitian ini dianalisis berdasarkan 6 (enam) faktor yaitu: kepadatan penduduk, kepadatan bangunan, kualitas bangunan, kelas jalan, jangkauan pos damkar yang dinilai dari waktu tempuh, dan jangkauan hydrant. Tahap awal yang dilakukan dalam analisis tingkat bahaya adalah menilai dan menghasilkan petapeta dari masing-masing faktor penentu bahaya kebakaran (Gambar 5).

Tingkat bahaya kebakaran diperoleh melalui proses overlay dari keenam faktor bahaya kebakaran dan hasilnya disajikan pada Tabel 3. Hasil tersebut menunjukkan bahwa kelas bahaya kebakaran yang paling dominan berada pada kelas sedang yang mencakup wilayah seluas 484,6 ha atau sebesar $89,3 \%$ dari luas total wilayah penelitian.

Tabel 3. Luas Kelas Bahaya Kebakaran di Kecamatan Tambora

\begin{tabular}{clcccccc}
\hline \multirow{2}{*}{ No } & Kelas Bahaya & Kebakaran & RW Kumuh & Luas (ha) & Karakteristik RW & \multicolumn{2}{c}{ Luas Kelas } \\
& RW Tidak Kumuh & Luas (ha) & Hektar & Persen \\
\hline 1. & Tinggi & 6 & 36,8 & 21 & 14,9 & 51,7 & 9,5 \\
2. & Sedang & 14 & 43,9 & 81 & 446,0 & 489,9 & 90,3 \\
3. & Rendah & & & 1 & 1,1 & 1,1 & 0,2 \\
& Jumlah & & 80,8 & & 461,9 & 542,7 & 100 \\
\hline
\end{tabular}

Berdasarkan hasil overlay antara peta bahaya kebakaran dengan peta sebaran RW kumuh (Gambar 6), didapatkan hasil sebagai berikut:

1. Luas sebaran RW kumuh mendominasi kelas bahaya tinggi yaitu seluas 36,8 ha atau $71,3 \%$ dari luas total kelas bahaya kebakaran tinggi. Sebaran RW kumuh yang banyak terdapat di dalam kelas bahaya kebakaran tinggi, disebabkan RW kumuh memiliki tingkat kepadatan penduduk yang tinggi, kepadatan bangunan tinggi, kualitas bangunan sedang, dan jarak yang jauh dari jangkauan hydrant. Jika dilihat dari jangakuan waktu tempuh pemadam kebakaran, wilayah dengan bahaya tinggi sebenarnya masuk ke dalam jangkauan waktu tempuh kurang dari 5 menit, akan tetapi karakteristik kelas jalan yang sebagian besar merupakan jalan lokal maka menjadikan pergerakan mobil damkar menjadi terhambat pada waktu menuju ke lokasi kejadian kebakaran. Sehingga daerah ini termasuk kelas bahaya yang tinggi. 

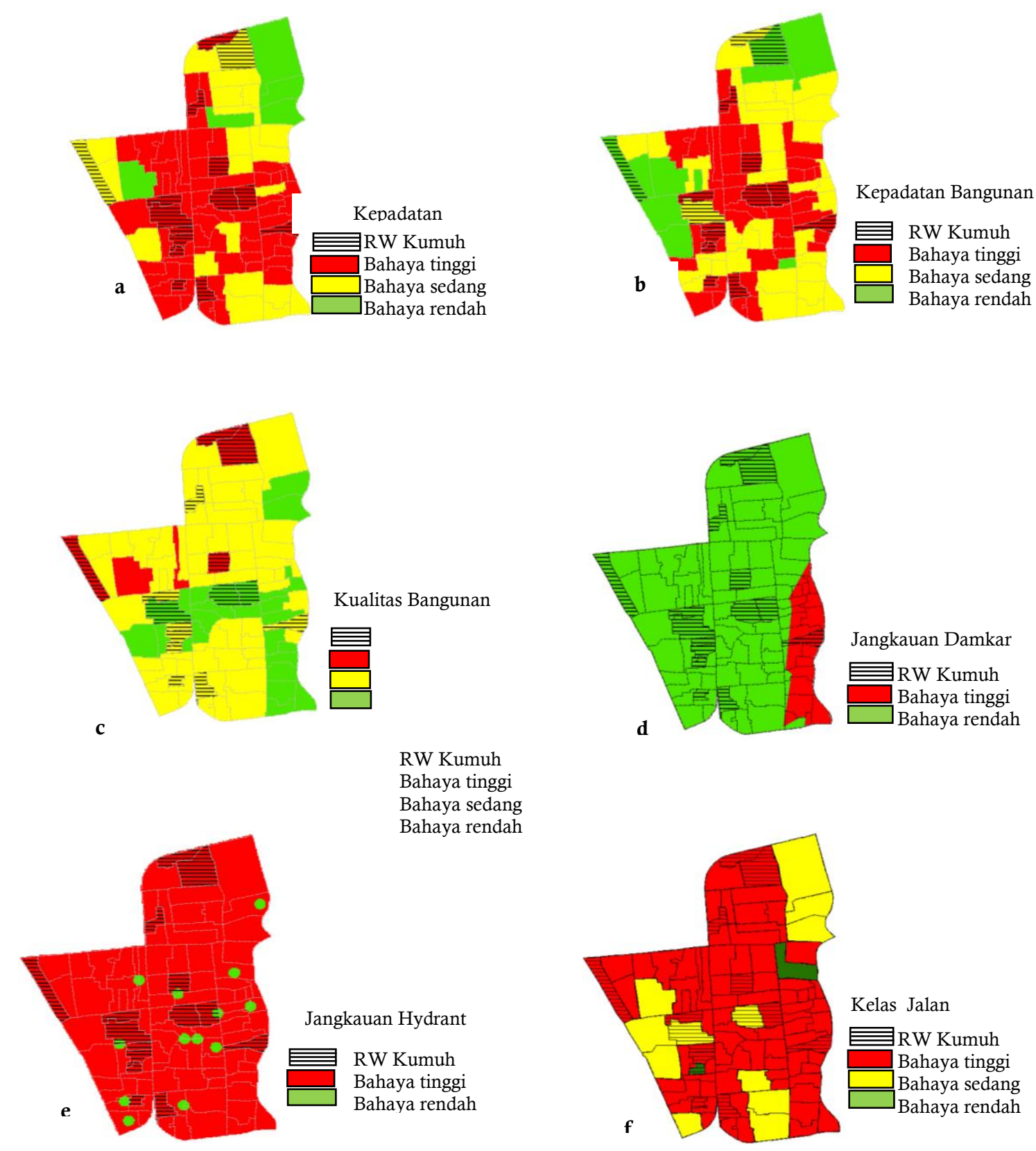

Gambar 5 Tingkat Bahaya Kebakaran Untuk Masing-Masing Faktor

2. Kelas bahaya kebakaran sedang mempunyai luas yang paling dominan di Kecamatan Tambora yaitu seluas 489,9 ha. Karakteristik sebagian besar RW yang masuk ke dalam kelas bahaya sedang adalah RW yang tidak kumuh. Dari total 95 RW yang masuk ke dalam kelas bahaya sedang hanya $15 \%$ atau $14 \mathrm{RW}$ saja yang masuk ke dalam kategori RW kumuh. Karakteristik RW kumuh yang masuk ke dalam kelas bahaya sedang sebagian besar adalah RW kumuh yang memiliki kualitas bangunan rumah sedang hingga baik. Kualitas rumah yang sudah mulai baik menyebabkan tingkat bahaya kebakaran menjadi turun. Selain itu karakteristik RW yang masuk ke dalam wilayah kelas bahaya sedang adalah RW yang mempunyai tingkat kepadatan penduduk yang rendah tetapi tingkat kepadatan bangunan tinggi, kualitas rumah 
sedang, dan kelas jalan dominan adalah jalan kolektor. Dilihat dari faktor jangkauan waktu tempuh pemadam kebakaran, wilayah kelas bahaya sedang masih tergolong ke dalam jangkauan waktu yang ditetapkan sesuai standar, yaitu kurang dari 5 menit. Seharusnya wilayah ini masuk ke dalam kelas yang rendah tetapi karena tingginya kepadatan bangunan maka menjadikan kelas bahaya menjadi sedang. Jarak yang rapat antar bangunan membuat api menjadi cepat menjalar sehingga wilayah yang terdampak biasanya menjadi meluas.

3. Kelas bahaya rendah mempunyai luas yang paling kecil yaitu seluas 1,1 hektar atau sebesar $0,2 \%$ dari total luas Kecamatan Tambora. Hal ini menggambarkan bahwa Kecamatan Tambora memang merupakan Kecamatan yang mempunyai ancaman tinggi terhadap kejadian kebakaran dan di kelas bahaya kebakaran rendah ini tidak terdapat sebaran RW kumuh.

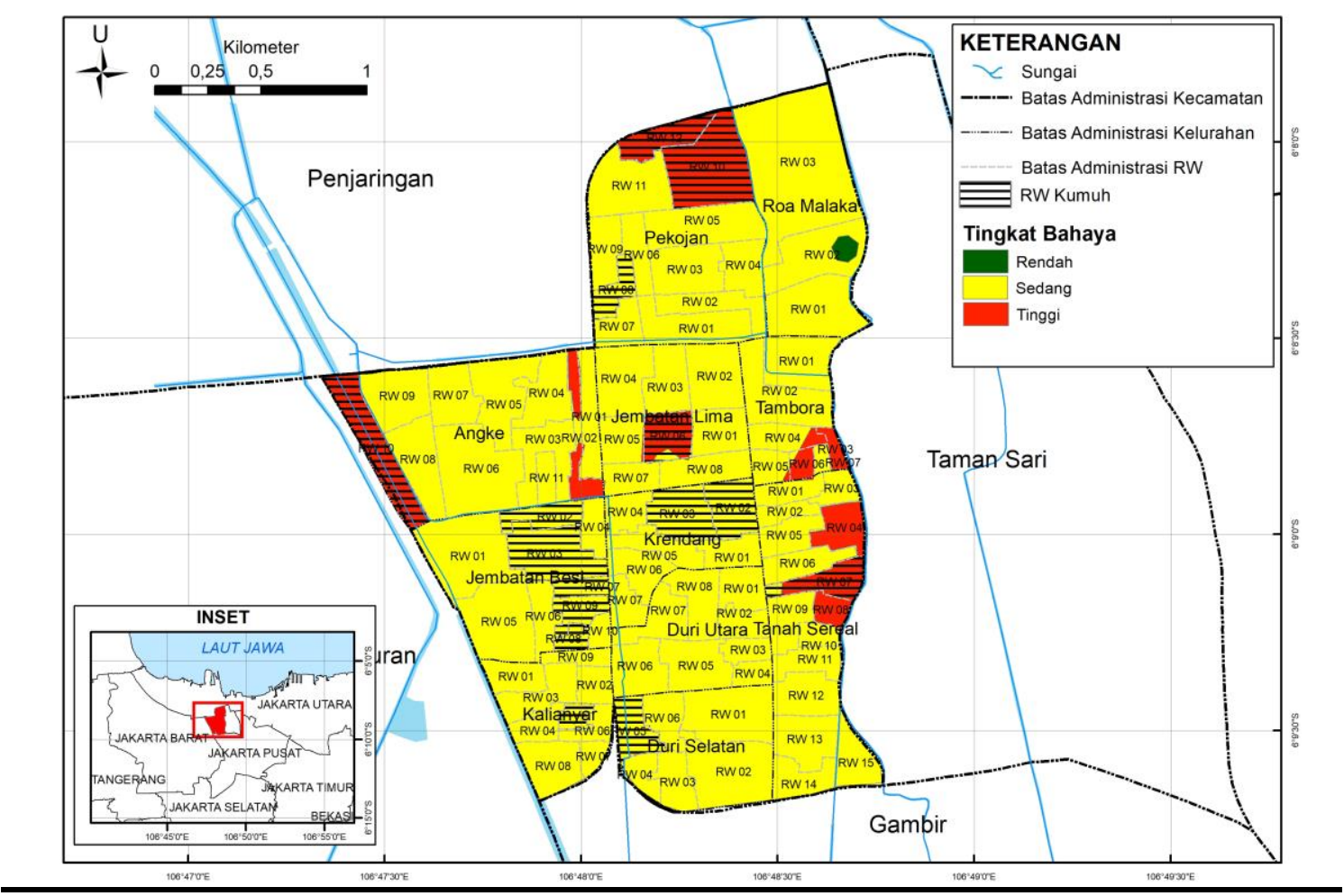

Gambar 6 Peta Tingkat Bahaya Kebakaran di Kecamatan Tambora

\section{Tingkat Kerentanan Wilayah}

Kerentanan adalah suatu kondisi yang ditentukan oleh faktor-faktor atau prosesproses fisik, sosial, ekonomi, dan lingkungan yang mengakibatkan peningkatan kerawanan masyarakat dalam menghadapi bahaya (Kurniawan et al. 2011). Faktor kerentanan yang digunakan dalam penelitian ini adalah kerentanan sosial (kelompok umur dan tingkat pendidikan) dan kerentanan ekonomi (tingkat pendapatan). Tahap awal yang dilakukan dalam analisis tingkat kerentanan adalah membuat peta tingkat kerentanan masing-masing faktor kerentanannya (Gambar 7). Hasil analisis melalui overlay dari faktor kerentanan menunjukkan bahwa Kecamatan Tambora didominasi oleh kelas kerentanan kelas sedang yaitu mencakup wilayah sebesar $66,4 \%$ dari total luas penelitian, selanjutnya kelas 
kerentanan tinggi sebesar $26,8 \%$ dan yang terkecil adalah kelas kerentanan rendah sebesar $6,7 \%$ (Tabel 4).

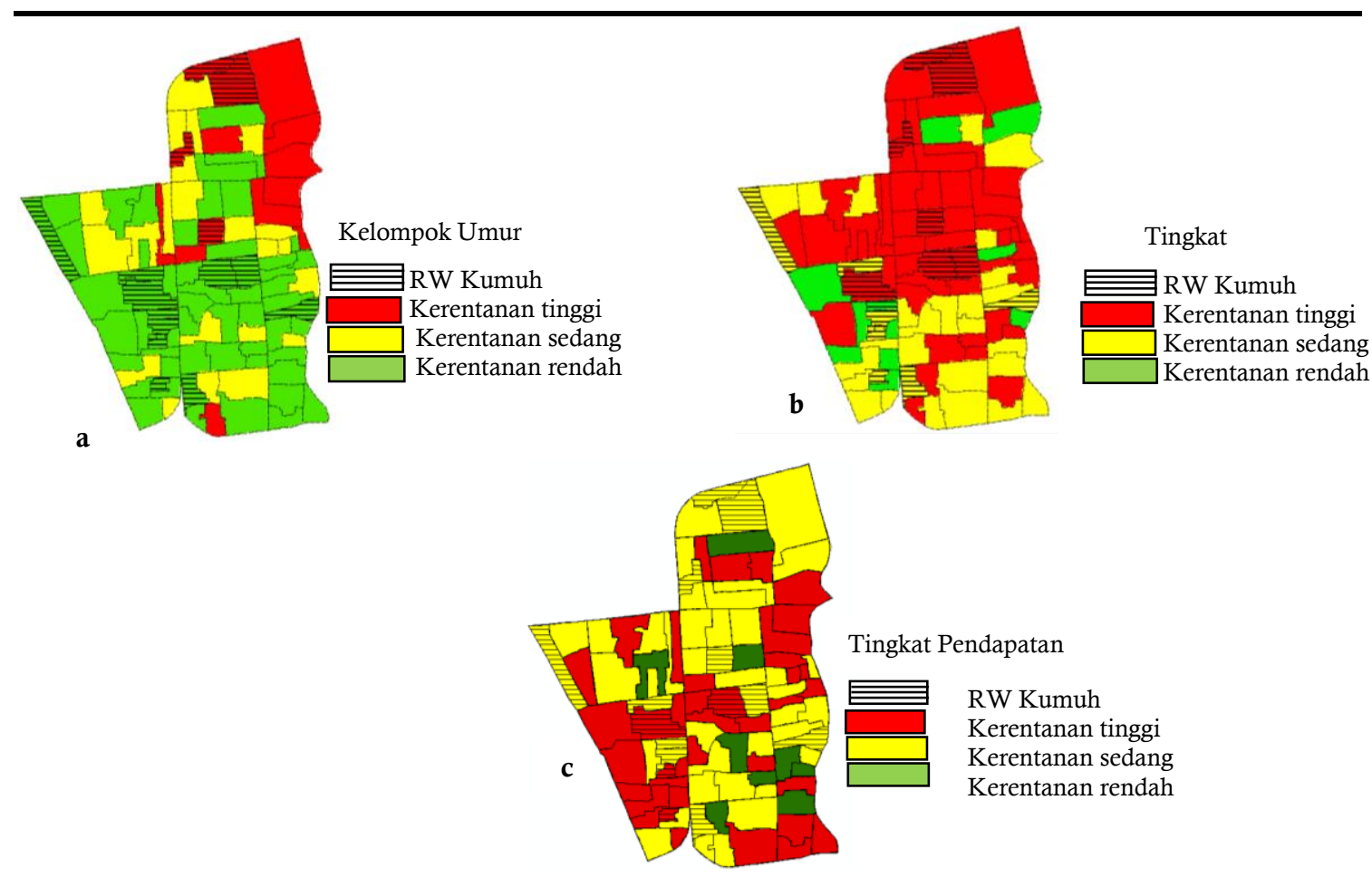

Gambar 7. Tingkat Kerentanan Untuk Masing-Masing Faktor

Tabel 4 Luas Kelas Kerentanan di Kecamatan Tambora

\begin{tabular}{cccccccc}
\hline \multirow{2}{*}{ No } & Kelas & \multicolumn{4}{c}{ Karakteristik RW } & \multicolumn{2}{c}{ Luas Kelas } \\
\cline { 3 - 8 } & Kerentanan & RW Kumuh & Luas (ha) & RW Tidak Kumuh & Luas (ha) & Hektar & Persen \\
\hline \multirow{2}{*}{1.} & Tinggi & 4 & 26,7 & 16 & 119 & 145,7 & 26,8 \\
2. & Sedang & 10 & 51,8 & 57 & 308,6 & 360,4 & 66,4 \\
3. & Rendah & 1 & 2,3 & 8 & 34,3 & 36,6 & 6,7 \\
\hline \multicolumn{2}{r}{} & Jumlah & 80,8 & & 461,9 & 542,7 & 100 \\
\hline
\end{tabular}

Hasil overlay antara peta kerentanan dengan sebaran RW kumuh menghasilkan peta seperti yang disajikan pada Gambar 8. Kelas kerentanan sedang terdiri dari $10 \mathrm{RW}$ kumuh dan 57 RW tidak kumuh dengan karakteristik sebagai berikut: jumlah penduduk kelompok umur lansia dan anak-anak sebesar 58\%, 42\% penduduk mempunyai latar belakang pendidikan tamat SMA, dan $43 \%$ penduduk memiliki pendapatan berkisar antara Rp. 2.000.000 - Rp. 3.500.000. Luas kelas kerentanan yang menduduki urutan kedua terbesar adalah kelas kerentanan tinggi. Jumlah RW pada kelas kerentanan tinggi terdiri dari 4 RW kumuh dan 16 RW tidak kumuh. Pada kelas kerentanan tinggi persentase penduduk pada kelompok umur rentan adalah lansia dan anak-anak sebesar $63 \%$. Selain itu persentase penduduk sebagian besar memiliki pendidikan tamat SMP sebesar 79\% bahkan terdapat penduduk tidak tamat SD sebesar $1 \%$ dan $54 \%$ penduduk mempunyai tingkat pendapatan Rp. 2.000.000 - Rp. 3.500.000. Sebaran di dalam kelas kerentanan rendah terdiri dari 1 RW kumuh dan 8 RW tidak kumuh. Karakteristik penduduk pada 
kelas kerentanan rendah adalah lebih dari $60 \%$ penduduknya berada pada kelompok umur dewasa, 95\% penduduk memiliki latar belakang pendidikan lulus SMA, dan 66\% penduduknya mempunyai tingkat pendapatan antara Rp. 2.000.000 - Rp. 3.500.000.

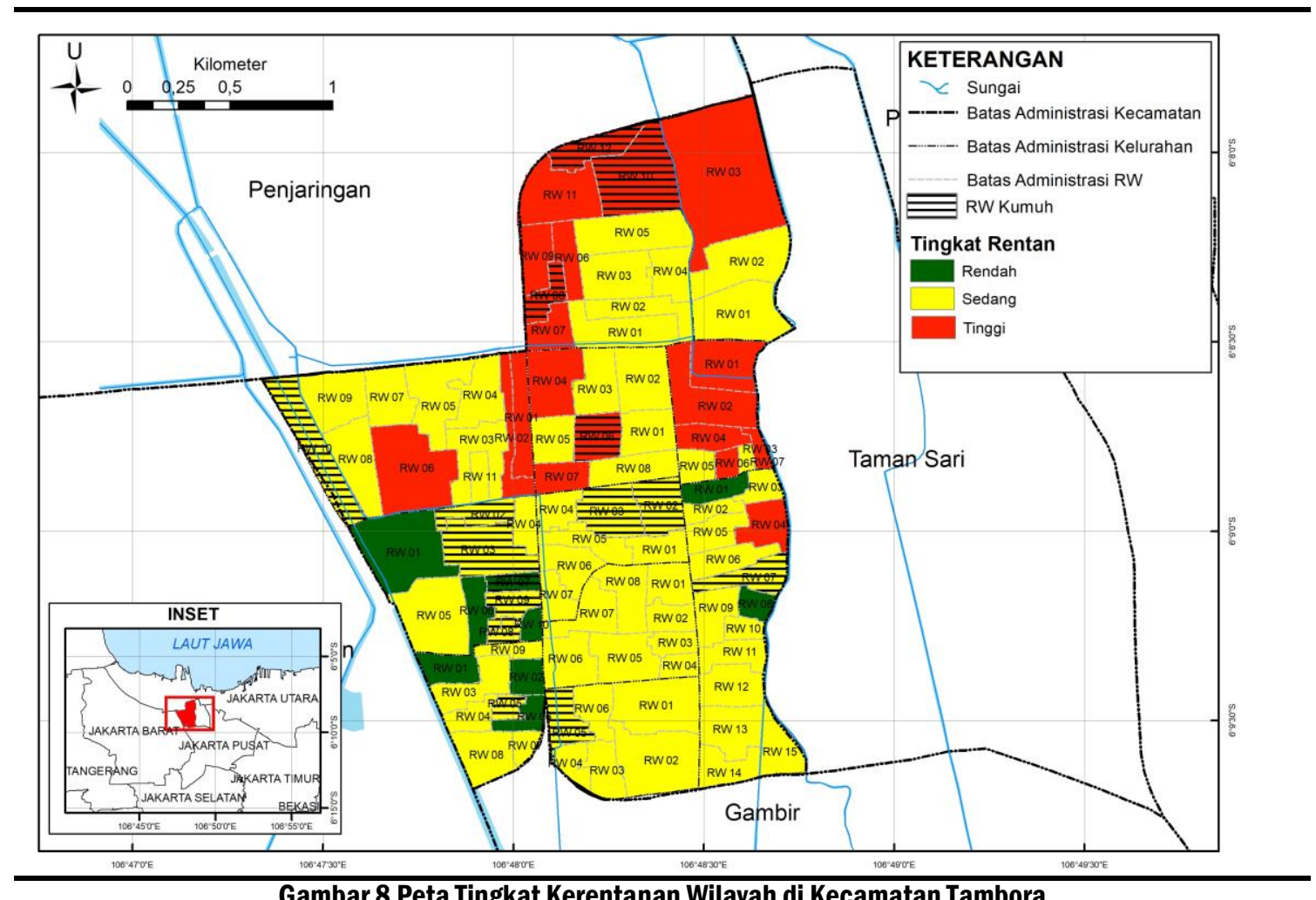

Gambar 8 Peta Tingkat Kerentanan Wilayah di Kecamatan Tambora

\section{Tingkat Risiko Bencana Kebakaran}

Tingkat risiko kebakaran didapatkan dari hasil overlay antara peta bahaya dan peta kerentanan berdasarkan matriks bahaya kerentanan. Dari hasil analisis risiko bencana kebakaran, sebagaimana disampaikan pada Tabel 5, diperoleh hasil bahwa Kecamatan Tambora memiliki kelas risiko rendah hingga tinggi. Dengan kelas risiko sedang memiliki luasan terbesar, yaitu 65,7\% dari luas total Kecamatan Tambora, sedangkan kelas risiko kebakaran yang memiliki luasan terkecil adalah kelas risiko rendah sebesar 6,5\% dari luas total Kecamatan Tambora.

Tabel 5 Tingkat Risiko Bencana Kebakaran di Kecamatan Tambora

\begin{tabular}{|c|c|c|c|c|c|c|c|}
\hline \multirow[b]{2}{*}{ No } & \multirow{2}{*}{$\begin{array}{l}\text { Kelas } \\
\text { Risiko }\end{array}$} & \multicolumn{4}{|c|}{ Karakteristik RW } & \multicolumn{2}{|c|}{ Luas Kelas } \\
\hline & & $\begin{array}{c}\text { RW } \\
\text { Kumuh }\end{array}$ & $\begin{array}{l}\text { Luas } \\
\text { (ha) }\end{array}$ & RW Tidak Kumuh & $\begin{array}{c}\text { Luas } \\
\text { (ha) }\end{array}$ & ha & Persen \\
\hline 1. & Tinggi & 6 & 31,3 & 36 & 119,4 & 150,7 & 27,8 \\
\hline 2. & Sedang & 12 & 47,1 & 75 & 309,7 & 356,8 & 65,7 \\
\hline 3. & Rendah & 6 & 2,4 & 20 & 32,8 & 35,2 & 6,5 \\
\hline \multicolumn{2}{|c|}{ Jumlah } & & 80,8 & & 461,9 & 542,7 & 100 \\
\hline
\end{tabular}

Sebaran RW kumuh dari hasil analisis risiko kebakaran menunjukkan bahwa RW kumuh terbanyak (12 RW) terdapat pada kelas risiko sedang, selanjutnya kelas risiko tinggi dan rendah masing-masing sebanyak 6 RW (Gambar 9). 


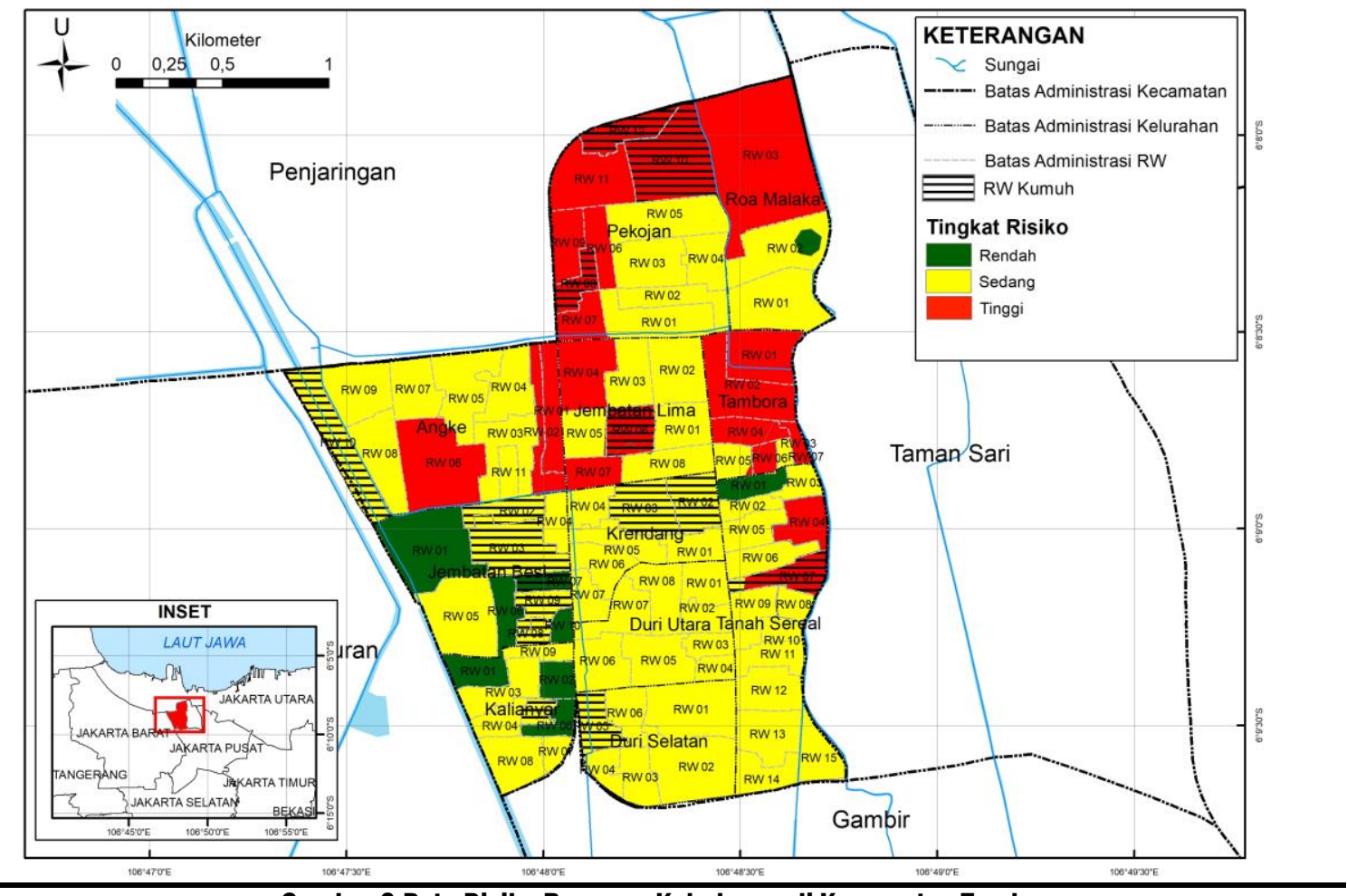

Gambar 9 Peta Risiko Bencana Kebakaran di Kecamatan Tambora

Banyaknya jumlah RW pada kelas risiko sedang (87 RW) disebabkan mayoritas tingkat bahaya RW tersebut berada di tingkat sedang dengan tingkat kerentanan sedang. RW pada kelas risiko tinggi berjumlah $42 \mathrm{RW}$ hal ini disebabkan tingkat bahaya dan kerentanan RW tersebut berada di tingkat tinggi. Jumlah RW yang paling sedikit berada di kelas risiko rendah ada $26 \mathrm{RW}$, dan memiliki tingkat bahaya sedang dan kerentanan rendah.

Pada kelas risiko rendah terdapat satu RW kumuh yang memiliki luasan paling besar yaitu RW 07 Kelurahan Jembatan Besi. Hal ini menggambarkan bahwa wilayah kumuh yang mempunyai tingkat bahaya sedang belum tentu memiliki risiko yang tinggi karena penentuan tingkat risiko tidak hanya ditentukan oleh faktor bahaya saja tetapi juga ditentukan oleh tingkat kerentanannya. RW 07 Kelurahan Jembatan Besi merupakan RW kumuh dengan tingkat bahaya sedang, tetapi mempunyai kerentanan rendah sehingga RW 07 berada pada kelas risiko rendah. Kecilnya luasan wilayah dengan risiko rendah pada Kecamatan Tambora, menggambarkan bahwa Kecamatan Tambora merupakan daerah rawan kebakaran.

Kelas risiko kebakaran sedang terbentuk pada daerah-daerah dengan tingkat bahaya sedang dan tinggi yang dicirikan oleh kondisi fisik wilayah yang mempunyai karakteristik kepadatan bangunan tinggi, kepadatan penduduk tinggi yang disertai dengan tingginya aktivitas penduduk, lebar jalan yang sempit serta tidak terjangkau oleh hydrant. Karakteristik tersebut banyak dijumpai pada permukiman kumuh, sehingga sebagian besar RW kumuh terdapat di kelas risiko sedang.

Kelas risiko kebakaran tinggi terbentuk pada daerah-daerah yang mempunyai kerentanan tinggi yang dicirikan oleh persentase kelompok umur lansia dan anak-anak yang lebih banyak, tingkat pendidikan yang rendah (sebagian besar hanya tamat SMP) dan sebagian besar yaitu $85 \%$ penduduk memiliki pendapatan dibawah Rp. 3.500.000,-.

Luas wilayah risiko kebakaran dilihat secara administratif (Tabel 6), menunjukkan bahwa Kelurahan Jembatan Besi memiliki kelas risiko kebakaran rendah terluas yaitu 21,1 ha atau sekitar 3,9\% dan Kelurahan Roa Malaka memiliki kelas risiko kebakaran rendah 
yang paling kecil yaitu 1,1 ha atau sekitar $0,2 \%$. Untuk kelas kebakaran sedang yang terluas berada di Kelurahan Angke yaitu 56,3 ha atau sekitar 10,4\% dan yang terkecil berada di Keluarahan Tambora 3,6 ha atau sekitar 0,7\%. Sementara itu untuk kelas risiko kebakaran tinggi yang terluas berada di Kelurahan Pekojan yaitu 44,2 ha atau sekitar 8,1\% dan yang terkecil berada di Keluarahan Jembatan Besi yaitu 0,1 ha atau sekitar 0,02\%. Dilihat dari sebaran kelas risiko sedang yang paling dominan, maka dapat dikatakan bahwa Kecamatan Tambora memiliki risiko terjadi kebakaran hampir di seluruh wilayahnya. Berdasarkan sebaran spasial, kelurahan dengan risiko bencana kebakaran tinggi adalah Kelurahan Tambora, Tanah Sereal, Angke, Jembatan Besi, Jembatan Lima, Pekojan, dan Roa Malaka, untuk itu diperlukan perhatian dalam penanganan penanggulangan ataupun pencegahan kebakaran serta peningkatan tingkat kewaspadaan pada ketujuh daerah tersebut.

Tabel 6 Luas Wilayah Risiko Bencana Kebakaran pada Masing-Masing Kelurahan

\begin{tabular}{lccc}
\hline \multicolumn{1}{c}{ Kelurahan } & \multicolumn{3}{c}{ Kelas Risiko Kebakaran (ha) } \\
& Rendah & Sedang & Tinggi \\
\hline Tambora & & 3,6 & 24,8 \\
Kalianyar & 9,6 & 20,9 & \\
Duri Utara & & 37,1 & \\
Tanah Sereal & 3,3 & 49,7 & 9,6 \\
Krendang & & 33,1 & 0,1 \\
Jembatan Besi & 21,1 & 32,6 & 23,5 \\
Angke & & 56,3 & 16,9 \\
Jembatan Lima & & 29,4 & 44,2 \\
Pekojan & & 35,7 & 31,4 \\
Roa Malaka & 1,1 & 20,2 & \\
Duri Selatan & & 38,3 & 150,7 \\
Jumlah & 35,2 & 356,8 & 27,8 \\
Presentase (\%) & 6,5 & 65,7 & \\
\hline
\end{tabular}

\section{KESIMPULAN}

Tingkat risiko bencana kebakaran di Kecamatan Tambora didominasi oleh kelas risiko sedang sebesar $65,7 \%$, kelas risiko tinggi $27,8 \%$, dan yang terkecil kelas risiko rendah $6,5 \%$. Dilihat dari besarnya luas wilayah yang masuk ke dalam kelas risiko sedang dan tinggi, menunjukkan bahwa Kecamatan Tambora memang merupakan kecamatan yang rawan terhadap kejadian kebakaran. Sebaran RW kumuh dari hasil analisis risiko kebakaran adalah sebanyak $12 \mathrm{RW}$ terdapat pada kelas risiko sedang, kelas risiko tinggi dan risiko rendah masing-masing sebanyak 6 RW kumuh. Banyaknya RW kumuh yang terdapat di dalam kelas risiko sedang menunjukkan bahwa daerah dengan tingkat kepadatan penduduk dan kerapatan bangunan yang tinggi, kualitas lingkungan yang menurun, sarana prasarana lingkungan yang tidak memadai, serta kepedulian masyarakat yang rendah menyebabkan wilayah tersebut menjadi berpotensi tinggi untuk terjadi kebakaran.

Faktor penentu bahaya kebakaran yang memberikan kontribusi tinggi terhadap ancaman bahaya kebakaran adalah jumlah hydrant yang kurang memadai dan lebar jalan yang sempit tidak dapat diakses oleh mobil pemadam kebakaran. Sehingga untuk mengurangi tingkat risiko maka tindakan mitigasi dengan melakukan intervensi terhadap faktor penentu bahaya dalam hal ini penambahan sumber air seperti hydrant dan penambahan lebar jalan agar dapat dilalui oleh mobil pemadam kebakaran perlu dilakukan. Hal ini sesuai dengan penelitian sebelumnya yang menyebutkan tindakan mitigasi yang perlu dilakukan pada permukiman padat adalah penambahan sumber air (hydrant) dan memberi kemudahan akses bagi ruang gerak mobil pemadam kebakaran (Mantra, 2005). 


\section{DAFTAR PUSTAKA}

Adilla Y, Adyatma S, Arisanty D. (2016). Faktor Penyebab Kerentanan Kebakaran berdasarkan Persepsi Masyarakat di Kelurahan Melayu Kecamatan Banjarmasin Tengah. Jurnal Pendidikan Geografi. 3(4), 4057.

[BNPB] Badan Nasional Penanggulangan Bencana. 2012. Peraturan Kepala Badan Nasional Penanggulangan Bencana Nomor 2 Tahun 2012 tentang Pedoman Umum Pengkajian Risiko Bencana. Jakarta (ID) : BNPB.

[BPS Provinsi DKI Jakarta] Badan Pusat Statistik. 2017a. DKI Jakarta Dalam Angka 2017. DKI Jakarta (ID) : BPS Provinsi DKI Jakarta.

[BPS Provinsi DKI Jakarta] Badan Pusat Statistik. 2017b. Pendataan RW Kumuh DKI Jakarta 2017. DKI Jakarta (ID) : BPS Provinsi DKI Jakarta.

Fransisca R, Adyatma S, Nugroho AR. (2014). Kerentanan Kebakaran di Kelurahan Sungai Andai Kecamatan Banjarmasin Utara Kota Banjarmasin. Jurnal Pendidikan Geografi. 1(2), 90-102.

Hapsari S. (2017). Peran Self Regulator dalam Meningkatkan Kemampuan Berpikir Kreatif sebagai Upaya Menyiapkan Generasi Emas 2045. Jurnal Pedagogika dan Dinamika Pendidikan. 6(1), 1-11.

Kurniawan L, Yunus R, Amri NR, Pramudiarta N. (2011). Indeks Rawan Bencana Indonesia. Jakarta: Badan Nasional Penanggulangan Bencana.

Mantra IBGW. (2005). Kajian Penanggulangan Bahaya Kebakaran pada Perumahan (Suatu Kajian Pendahuluan di Perumahan Sarijadi Bandung). Jurnal Permukiman Natah. 3(1), 1-61.

Mononimbar W, Supardjo S, Wiarni S. (2018). Analisis Tingkat Kekumuhan Kawasan Permukiman di Kecamatan Kotamobagu Timur. Jurnal Spasial. 5(1), 61-70.

Musungu K, Motala S, Smith J. (2012). Using Multi Criteria Evaluation and GIS for Flood Risk Analysis in Informal Settlement of Cape Town: The Case of Graveyard Pond. South African Journal of Geomatics. 1(1), 92-108.

Nasution Y. (2012). Mitigasi Kebakaran melalui Masyarakat. Jurnal Kesehatan Masyarakat Nasional. 6(4), 179184.

Oktaviansyah E. (2012). Penataan Permukiman Kumuh Rawan Bencana Kebakaran di Kelurahan Lingkas Ujung Kota Tarakan. Jurnal Tata Kota dan Daerah. 4(2), 159-167.

Pawesti D, Sihwi SW. (2012). Perbandingan Penggunaan Metode AHP dan SAW untuk Sistem Pendukung Keputusan. Jurnal ITSMART. 1(2), 74-81.

Suweda IW. (2011). Penataan Ruang Perkotaan yang Berkelanjutan, Berdaya Saing dan Berotonomi. Jurnal Ilmiah Teknik Sipil. 15(2), 113-122.

Syaufina L. (2008). Kebakaran Hutan dan Lahan di Indonesia, Perilaku Api, Penyebab dan Dampak Kebakaran. Malang: Banyumedia Publishing.

Taridala S, Yudono A, Ramli MI, Akil A. (2018). Model Penentuan Sistem Jaringan Air Bersih untuk Mitigasi Bencana Kebakaran Perkotaan dengan Sistem Pakar Berbasis SIG. Jurnal Ilmu Komputer. 5(1), 37-48. 